\title{
PEMBERDAYAAN PEREMPUAN UNTUK KESETARAAN \& MENINGKATKAN PARTISIPASI DALAM PEMBANGUNAN LINGKUNGAN HIDUP
}

\author{
Oleh: Suriani Nur \\ Dosen tetap Jurusan Tarbiyah STAIN Watampone
}

\begin{abstract}
:
Woman is one a human resource which is potential to be involved in development of environment. Amount of resident of Indonesia has plentyof woman gender to, despitefully woman represent environmental manager is suitable arrange natural resources and environment. Lack of knowledge of environment is one of the factor thatcause involvement of woman in development become minim. Conductingwomanparticipation is important to continue to improve woman clan self-capacities so that they can have self-confidence. Consequently woman clan can follow to participate and also act in all development in Indonesia which included in development of environment.
\end{abstract}

\begin{abstract}
Abstrak:
Perempuan merupakan sumber daya manusia yang pontensial untuk dilibatkan dalam pembangunan lingkungan hidup. Jumlah penduduk Indonesia yang berjenis kelamin perempuan sangat banyak, di samping itu perempuan merupakan manager lingkungan yang sangat baik untuk dapat menata sumber daya alam dan lingkungan hidup. Kurangnya pengetahuan lingkungan merupakan salah satu faktor sehingga keterlibatan perempuan dalam pembangunan lingkungan hidup minim. Pemberdayaan perempuan penting dilakukan untuk terus meningkatkan kapasitas diri kaum perempuan agar dapat memiliki kepercayaan diri sehingga kaum perempuan dapat ikut berpartisipasi serta berkipra dalam semua lini pembangunan di Indonesia termasuk dalam pembangunan lingkungan hidup.
\end{abstract}

Kata Kunci: Pemberdayaan, Perempuan, lingkungan hidup

\section{PENDAHULUAN}

Lingkungan hidup tidak dapat dipisahkan dari kehidupan manusia karena. alam telah menyediakan segala kebutuhan hidup manusia. Manusia mendapatkan semua kebutuhan untuk hidup dari alam, baik berupa makanan dari tumbuhan dan hewan, bernafas dari oksigen di udara yang tersedia tanpa batas di atmosfir, air yang melimpah yang tersedia dalam berbgai wujud baik padat, cair maupun gas dan berbagai materi lainnya. Lingkungan hidup merupakan bagian yang sangat 
penting dalam kehidupan manusia, karena bukan saja sebagai tempat manusia beraktifitas tetapi juga berperan dalam berbagai aktivitas kehidupan.

Lingkungan hidup sebagai tempat manusia berada merupakan tatanan alam sebagai ciptaan Allah, apa yang dikehendaki-Nya bersifat absolut (tanpa batas), berbeda halnya pengetahuan dan kemampuan manusia secara relatif sangat terbatas. Melalui pelatihan dan pendidikan maka kecerdasan, kemampuan maupun keterampilan kapasitas manusia dapat ditingkatkan secara berangsur-angsur. Makna pendidikan sebenarnya bukan semata-mata untuk mengelola atau menata lingkungan tetapi kemampuan untuk menata sikap dan mengatur perilaku agar serasi dengan tatanan alam yang sudah tercipta secara tertib dan teratur ${ }^{1}$.Pemberdayaan perempuan perlu dipersiapkan dan dilaksanakan secara terencana, terarah, terpadu dan berlanjut agar sumber daya ini dapat dioptimalkan perannya dalam kehidupan terutama dalam pembangunan lingkungan hidup.

Berbagai kasus lingkungan hidup yang terjadi sekarang ini, baik pada lingkungan global maupun lingkup nasional, sebagian besar bersumber dari perilaku manusia. kasus-kasus pencemaran dan kerusakan seperti di laut, hutan, atmosfer, air, tanah dan seterusnya bersumber dari perilaku manusia yang tidak bertanggung jawab, tidak peduli dan hanya mementingkan diri sendiri. ${ }^{2}$

Oleh Karena itu etika lingkungan harus menjadi sebuah gerakan bersama secara global dengan melibatkan semua kelompok masyarakat untuk bisabersamasama membangun budaya baru, etika baru, gaya hidup baru sebagai gerakan menjadikan gerakan kearifan merawat bumi sebagai sebuah rumah tangga untuk menjadikan tempat nyaman bagi kehidupan. Melalui gerakan bersama seperti itu budaya baru bias dimulai, diajarkan, dan diwariskan dari satu orang ke orang yang lai, dari satu kelompok ke kelompok yang dan dari satu generasi ke generasi yang lainnya ${ }^{3}$.

\section{PEMBAHASAN}

\footnotetext{
${ }^{1}$ Soerjani, Muhammad. 2009. Pendidikan Lingkungan (Environmental Education) Sebagai Dasar Sikap dan Perilaku Bagi Kelangsungan Kehidupan Menuju Pembangunan Berkelanjutan. Jakarta: Institut Pendidikan dan Pengembangan Lingkungan. h. 54 ${ }^{2}$ Sony Keraf . 2010. Etika Lingkungan Hidup. (Cet I, Jakarta: Penerbit Buku Kompas) h.1.

${ }^{3}$ Sony Keraf. 2010.h. 10
} 


\section{A. Pengertian pemberdayaan}

Pemberdayaan berasal dari kata dasar 'daya' yang berarti kemampuan melakukan sesuatu atau kemampuan bertindak. Daya yang mendapat awalan bersehingga menjadi kata 'berdaya' artinya memiliki atau mempunyai daya, berkekuatan, berkemampuan, mempunyai akal untuk mengatasi sesuatu. Sehingga Pemberdayaan artinya membuat berdaya, membuat sesuatu menjadi berdaya atau mempunyai daya/kekuatan ${ }^{4}$.

Secara etimologis pemberdayaan berasal dari kata dasar "daya" yang berarti kekuatan atau kemampuan. Pemberdayaan dimaknai sebagai proses untuk memperoleh daya, kekuatan atau kemampuan, dan atau proses pemberian daya, kekuatan atau kemampuan dari pihak yang memiliki daya kepada pihak yang kurang atau belum berdaya. Hakekat pemberdayaan adalah suatu proses dan upaya untuk memperoleh atau memberikan daya, kekuatan atau kemampuan kepada individu dan masyarakat lemah agar dapat mengidentifikasi, menganalisis, menetapkan kebutuhan dan potensi serta masalah yang dihadapi dan sekaligus memilih alternatif pemecahannya dengan mengoptimalkan sumber daya dan potensi yang dimiliki secara mandiri ${ }^{5}$.

Pemberdayaan merupakan upaya yang dilakukan oleh masyarakat, dengan atau tanpa dukungan pihak luar, untuk memperbaiki kehidupannya yang berbasis kepada daya mereka sendiri, melalui optimasi daya serta peningkatan posisi tawar yang dimiliki. ${ }^{6}$ Pemberdayaan adalah upaya untuk meningkatkan kemampuan dan potensi yang dimiliki oleh suatu masyarakat sehingga mereka dapat mengaktualisasikan jati diri, harkat dan martabatnya secara maksimal untuk bertahan dan mengembangkan diri secara mandiri. Hal ini dimaksudkan agar masyarakat dapat melepaskan diri dari perangkap kemiskinan dan keterbelakangan. Dengan demikian pemberdayaan adalah suatu upaya untuk

${ }^{4}$ Departemen Pendidikan Nasional. 2005. Kamus Besar Bahasa Indonesia. (Edisi ketiga. Jakarta: Balai Pustaka) .h. 241.

${ }^{5}$ Sulistiyani. 2004. Kemitraan dan Model-Model Pemberdayaan Masyrakat. (Yokyakarta: Gava Media). h.77

${ }^{6}$ Mardikanto, T.\& Soebiato, P. 2013. Pemberdayaan Masyarakat Dalam Perspektif Kebijakan Publik.(Bandung: Alfabeta.) h. 100 
meningkatkan kemampuan dan kemandirian, baik di bidang ekonomi, sosial budaya dan politik ${ }^{7}$.

Pemberdayaan masyarakat sebagai bentuk partisipasi membebaskan diri dari ketergantungan mental maupun fisik. Partisipasi masyarakat menjadi suatu elemen pokok dalam strategi pemberdayaan dan pembangunan masyarakat, dengan alasan; pertama, partisipasi masyarakat merupakan satu perangkat ampuh untuk memobilisasi sumber daya lokal, mengorganisir serta membuka tenaga, kearifan, dan kreativitas masyarakat. Kedua, partisipasi masyarakat juga membantu upaya identifikasi dini terhadap kebutuhan masyarakat ${ }^{8}$.

Mendidik masyarakat (termasuk perempuan) dalam meningkatkan kapasitas dikembangkan m:elalui berbagai cara berdasarkan kebutuhan masyarakat. Pelatihan berbasis masyarakat merupakan salah satu model pengembangan untuk merangsang pemahaman, peran dan keterampilan masyarakat. Pelatihan masyarakat dalam berbagai program pembangunan merupakan upaya transfer of knowledge dan memberikan sejumlah pengalaman baru yang bermanfaat bagi pengembangan peran dan memecahkan permasalahan yang dihadapi ${ }^{9}$.

Berdasarkan berbagai pengertian tentang pemberdayaan maka dapat dikatakan bahwa pemberdayaan merupakan suatu usaha yang dilakukan untuk membuat masyarakat terutama perempuan mampu memajukan diri sendiri dengan meningkatkan pengetahuan dan keterampilan yang dimiliki menuju kehidupan lebih baik. Pemberdayaan melalui pelatihan bagi masyarakat atau kaum perempuan berarti memberikan pendidikan pada perempuan, karena pemberdayaan melalui pelatihan, pada dasarnya suatu upaya membuat masyarakat khususnya kaum perempuan dengan segala kemampuannya agar dapat memberdayakan dirinya melalui peningkatan pengetahuan, sehingga memiliki kecenderungan sikap yang positif terkait suatu hal tertentu .

\footnotetext{
${ }^{7}$ Karwurf, dkk, 2010 h. 55.

${ }^{8}$ Ali, Madekhan. 2007. Pemberdayaan Masyarakat. (Jakarta:Averros Press.) h. 86

${ }^{9}$ Sumpeno, 2009. Sumpeno, Wahyudin. 2009. Sekolah Masyarakat Penerapan Rapid Training Design Dalam Pelatihan Berbasis Masyarakat. Yogyakarta: Pustaka Pelajar)h.46.
} 


\section{B. Pemberdayaan sebagai suatu program dan proses}

Sejatinya sebuah pemberdayaan adalah bertujuan untuk membuat seseorang mampu melakukan sesuatu secara mandiri tanpa harus tergantung pada orang lain. Kemandirian yang ada sebagai hasil dari sebuah pemberdayaan dalam bentuk kemandirian ekonomi, kemandirian politik dan sebagainya tergantung kepada jenis program yang ada. Pemberdayaan sebagai suatu kegiatan yang membuat orang dapat melakukan perubahan dalam dirinya dengan melalui sebuah proses yang dapat berlangsung secara singkat atau pun melalui sebuah proses yang panjang.

pemberdayaan dapat dilihat dari sisi keberadaannya sebagai suatu program ataupun sebagai suatu proses. Pemberdayaan sebagai suatu pogram, dimana pemberdayaan dilihat dari tahapan-tahapan kegiatan guna mencapai suatu tujuan, yang biasanya sudah ditentukan jangka waktunya ${ }^{10}$.

Proses pemberdayaan individu sebagai suatu proses yang relatif terus berjalan sepanjang usia manusia, yang diperoleh dari pengalaman individu tersebut dan bukannya suatu proses yang berhenti pada suatu masa saja (empowerment is not an end state, but a process that all human beings experience ). ${ }^{11}$ Hal ini juga berlaku pada suatu masyarakat, dimana dalam suatu komunitas proses pemberdayaan tidak akan berakhir dengan selesainya suatu program, baik program yang dilaksanakan oleh pemerintah maupun lembaga non pemerintah. Proses pemberdayaan akan berlamsung selama komunitas itu masih tetap ada dan mau berusaha memberdayakan diri mereka sendiri.

Proses pemberdayaan yang berkesinambungan sebagai suatu siklus yang terdiri dari lima tahapan utama, adalah: 1) menghadirkan kembali pengalaman yang memberdayakan dan tidak memberdayakan (recall depowering/empowering experiences), 2) Mendiskusikan alasan mengapa terjadi pemberdayaan dan penidakberdayaan (discuss reasons for depowerment lempowerment), 3) Mengidentifikasikan suatu masalah ataupun proyek ( identify one problem or project), 4) Mengidentifikasikan basis daya yang bermakna untuk melakukan

\footnotetext{
${ }^{10}$ Adi, Isbandi Rukminto. 2012. Intervensi Komunitas \& Pengembangan Masyarakat Sebagai Upaya Pemberdayaan Masyarakat. Jakarta: Rajawali Pers.) h. 211

${ }^{11}$ Hogen, Christine. 2000. Facilitating Empowerment: a Handbook for Facilitatos, Trainers and individuals.(London: Kogan Page Limited) h.13
} 
perubahan (identify useful power bases), dan Mengembangkan rencana-rencana aksi dan mengimplementasikannya (develop and implement action plans $)^{12}$ Kegiatan tersebut merupakan kegiatan yang dapat bersiklus.

\section{Pemberdayaan perempuan untuk kesetaraan}

Program pemberdayaan perempuan di Indonesia sudah dimulai sejak tahun 1978. Melalui pemberdayaan, beberapa daerah telah memperoleh hasil memadai dalam meningkatkan kapasitas diri, meningkatkan ekonomi, meningkatkan kesehatan, meningkatkan kualitas hidup kaum perempuan. Namun masih banyak perempuan di Indonesia yang belum tersentuh oleh program pemberdayaan baik di perkotaan terlebih di perdesaan.

Secara kuantitas jumlah penduduk perempuan Indonesia jauh lebih banyak dari pada laki-laki. Sebagian besar berdiam di perdesaan, tertinggal dan memiliki pendidikan yang rendah. Sumber daya ini akan menjadi beban jika tidak dimaksimalkan peran dan fungsinya dalam segala lini pembangunan. Sebaliknya, akan menjadi suatu sumber daya yang besar manfaatnya jika mampu di arahkan menjadi insan yang berdayaguna tinggi melalui pemberdayaan. Pemberdayaan perempuan merupakan suatu upaya mewujudkan kesetaraan perempuan dan lakilaki dalam akses, partisipasi, kontrol dan manfaat (APKM) di semua bidang pembangunan.

Berbagai langkah dapat dilakukan untuk menciptakan kesetaraan laki-laki dan perempuan atau kesetaraan gender, sehingga dapat terwujud peran yang seimbang antara laki-laki dan perempuan dalam keluarga untuk bersama-sama membangun dan mengembangkan perekonomian keluarga demi mencapai kesejahteraan keluarga. Meskipun upaya membangun kesetaraan gender tersebut telah dilakukan cukup lama, namun masih terdapat banyak hal dan sisi kehidupan yang belum mencerminkan adanya kesetaraan antara perempuan dan laki-laki. Kurangnya perhatian dan intensitas serta kesinambungan program pemberdayaan

\footnotetext{
${ }^{12}$ Hogen , 2000 h. 20.
} 
perempuan merupakan salah satu penyebab belum terciptanya kesetaraan gender ${ }^{13}$.

Pemberdayaan perempuan adalah proses penyadaran dan pembentukan kapasitas (capacity building) terhadap partisipasi yang lebih besar seperti keluasan, pengawasan, dan pengambilan keputusan serta tindak transformasi yang mengarah pada perwujudan persamaan derajat yang lebih besar antara perempuan dan laki-laki ${ }^{14}$.

Pemberdayaan perempuan dalam pengelolaan lingkungan diharapkan akan mengungkapkan keajaiban wanita sebagai manajer yang paling baik dalam menangani masalah lingkungan. Sehubungan dengan itu maka banyak hal yang dapat dilakukan perempuan sehingga dapat meningkatkan kualitas lingkungan. Meningkatkan pengetahuan, meningkatkan keterampilan, bentuk sikap dan perilaku menjadi sadar berbuat yang berkualitas. Ini berarti perempuan tidak hanya mau bekerja keras tetapi juga harus dapat bekerja secara cerdas dan ikhlas. Kalau perempuan yang diajarkan menangani ini berarti seluruh keluarga akan turut menanganinya, karena perempuan akan mengajarkan dan menularkannya. Banyak hasil kajian menunjukkan bahwa perempuan adalah manajer yang paling baik dalam penanganan lingkungan hidup ${ }^{15}$

Partisipasi perempuan sangat berkorelasi dengan kualitas lingkungan. Bila perempuannya aktif maka akan terlihat lingkungan bersih, hijau, teratur dan indah, sebaliknya jika terjadi kerusakan lingkungan, yang paling menderita adalah perempuan. Pengalaman dan perhatian perempuan terhadap lingkungan merupakan aset dalam pembangunan lingkungan. Perempuan yang menguasai ilmu pengetahuan, teknologi, dan seni menjadi menjadi agenda bangsa yang harus dilaksanakan secara terencana, terarah, terpadu, dan berkelanjutan. Jika perempuan tidak tahu dan tidak memahami, atau kurang pengetahuan dan

\footnotetext{
${ }^{13}$ Sri Marwanti1, Ismi Dwi Astuti. 2012. Model Pemberdayaan Perempuan Miskin Melalui Pengembangan Kewirausahaan Keluarga Menuju Ekonomi Kreatif Di Kabupaten Karanganyar.(Jurnal Sepa : Vol. 9 No.1), h.134

${ }^{14}$ Ma'arif, Syafi'i, 2003. Pembangunan dalam Perspektif Gender. (Malang: UMM Press.) h.189.

${ }^{15}$ Zoer'aini Djamal Irwan. 2009. Besarnya Eksploitasi Perempuan Dan Lingkungan Di Indonesia. (Jakarta: Alex Media Komputindo).h. xvii.
} 
keterampilan dalam pengelolaan lingkungan, merupakan kerugian dan akan berdampak negatif terhadap lingkungan ${ }^{16}$.

Tiga pilar prinsip Pembangunan Berkelanjutan (PB) yaitu aspek sosial, ekonomi, dan lingkungan hidup dilaksanakan dengan melibatkan seluruh pihak dalam masyarakat. Namun, keterlibatan masyarakat yang sangat esensial dalam pembangunan berkelanjutan ini masih terbatas dan belum menjadi suatu gerakan aksi nyata, padahal perempuan mempunyai potensi besar sebagai pelopor dalam pemeliharaan lingkungan.

Potensi perempuan yang besar dapat dikembangkan dalam pemeliharaan, pelestarian lingkungan dan pencegahan pencemaran lingkungan, karena selain jumlah perempuan cukup banyak juga telah banyak bukti bahwa perempuan telah mampu mengatasi masalah lingkungan di sekitarnya. Selama ini perempuan kurang diikut sertakan dalam pengelolaan lingkungan baik itu dalam akses, partisipasi, kontrol dan manfaat. Perempuan juga kurang diberi pengetahuan tentang cara pengelolaan lingkungan hidup. Penjelasan ayat (1) Pasal 70 UndangUndang nomor 32 tahun 2009 tentang Perlindungan dan Pengelolaan Lingkungan Hidup menyatakan, bahwa masyarakat memiliki hak dan kesempatan yang sama dan seluas-luasnya untuk berperan aktif dalam perlindungan dan pengelolaan lingkungan hidup. Melalui peran serta tersebut anggota masyarakat mempunyai motivasi kuat untuk bersama-sama mengatasi masalah lingkungan hidup dan mengusahakan berhasilnya kegiatan pengelolaan lingkungan hidup. Penjelasan ayat (2) menyatakan, bahwa peraturan perundang-undangan sebagaimana tersebut dalam ayat (2) itu mengatur tata laksana peran serta sebagaimana tersebut dalam ayat (1). Kedua ketentuan tersebut di atas, yaitu ketentuan dalam Pasal 70 Undang-Undang Nomor 32 Tahun 2009 tentang Perlindungan dan Pengelolaan Lingkungan Hidup telah memberikan landasan hukum yang kuat kepada peran serta masyarakat dalam pengelolaan lingkungan hidup.

Pemberdayaan perempuan memiliki makna yang mulia karena mengatur serta mengurus sumberdaya manusia dalam keluarga, terutama anak-anak sebagai generasi penerus bangsa. Memberikan pendidikan yang terbaik untuk kaum perempuan, berarti secara tidak langsung memberikan pendidikan pada individu

${ }^{16}$ Zoer'aini, 2009. h. 108 
lainnya dalam sebuah keluarga, maka suksesnya suatu rumah tangga, sangat tergantung pada kemampuan dan potensi memadai dari perempuan, sebagai isteri dan ibu rumah tangga. Sehingga untuk mendukung keberadaan dan ketersediaan sumberdaya manusia (generasi penerus) berkualitas dan berdaya saing tinggi di masa depan maka perempuan penting diberdayakan khususnya dari sisi pendidikan termasuk dalam hal pendidikan lingkungan hidup. Oleh karena itu strategi pengarusutamaan perempuan penting diposisikan di tempat utama dalam setiap strategi pembangunan. Pemberdayaan perempuan dalam meningkatkan kapasitas perempuan khususnya terkait dalam peningkatan pengetahuan lingkungan merupakan suatu yang perlu mendapat perhatian dari berbagai pihak. Agar sumber daya manusia yang cukup banyak jumlahnya di Indonesia dapat berdaya guna tinggi bagi pembangunan yang ramah lingkungan.

\section{Perempuan dan Pengelolaan Lingkungan Hidup}

Islam merupakanRahmatan lil 'alamin,maka sudah sewajarnya sebagai umat Islam, umat beriman menjadi pengelola lingkungan hidup yang baik termasuk perempuan juga ikut terlibat dalam pengelolaan lingkungan dan alam. Islam melarang membuat kerusakan di muka bumi dan mewajibkan untuk menjaga keberlanjutan bumi untuk kepentingan manusia itu sendiri.

Dan janganlah kamu membuat kerusakan di muka bumi, sesudah (Allah) memperbaikinya dan berdoalah kepada-Nya dengan rasa takut (tidak akan diterima) dan harapan (akan dikabulkan). Sesungguhnya rahmat Allah amat dekat kepada orang-orang yang berbuat baik.(QS. 7:56)

Manusia mempunyai tanggung jawab untuk memelihara dan memakmurkan alam sebagaimana firman Allah SWT.:

Dan kepada Tsamud (Kami utus) saudara mereka shaleh. shaleh berkata: "Hai kaumku, sembahlah Allah, sekali-kali tidak ada bagimu Tuhan selain Dia. Dia telah menciptakan kamu dari bumi (tanah) dan menjadikan kamu pemakmurnya, karena itu mohonlah ampunan-Nya, kemudian bertobatlah kepada-Nya. Sesungguhnya Tuhanku amat dekat (rahmat-Nya) lagi memperkenankan (doa hamba-Nya)." (QS. 11:61)

Islam telah memberikan peluang pada perempuan untuk dapat berbuat kebajikan di bumi ini dengan diberikan pahala yang sama dengan laki-laki. 
Persamaan antara laki-laki dan perempuan dalam kebebasan dan kewajiban bergama dan beribadah, Allah SWT berfirman sebagaimana dalam Alquran:

Sesungguhnya laki-laki dan perempuan yang muslim, laki-laki dan perempuan yang mukmin, laki-laki dan perempuan yang tetap dalam ketaatannya, laki-laki dan perempuan yang benar, laki-laki dan perempuan yang sabar, laki-laki dan perempuan yang khusyuk, laki-laki dan perempuan yang bersedekah, laki-laki dan perempuan yang berpuasa, lakilaki dan perempuan yang memelihara kehormatannya, laki-laki dan perempuan yang banyak menyebut (nama) Allah, Allah telah menyediakan untuk mereka ampunan dan pahala yang besar.( QS.33:35)

Dan orang-orang yang beriman, lelaki dan perempuan, sebahagian mereka (adalah) menjadi penolong bagi sebahagian yang lain. Mereka menyuruh (mengerjakan) yang makruf, mencegah dari yang mungkar, mendirikan shalat, menunaikan zakat, dan mereka taat kepada Allah dan Rasul-Nya. Mereka itu akan diberi rahmat oleh Allah; sesungguhnya Allah Maha Perkasa lagi Maha Bijaksana. (QS. 9: 71)

Peran perempuan sangat menentukan dalam pengelolaan lingkungan hidup yang baik, dan berperilaku yang tepat terhadap lingkungan hidup karena: Pertama, Jumlahnya yang banyak. Sebagai warganegara Indonesia, perempuan tidak dapat dinafikan lagi akan dapat berkonstribusi besar dalam pembangunan karena jumlahnya yang cukup besar. Jumlah perempuan yang besar akan menjadi berkah jika dioptimalkan pemanfaatannya dan akan jadi beban bagi negara jika dibiarkan tanpa arti dan makna. Oleh karena itu penting melibatkan dalam pembangunan, yang didahului dengan peningkatan kapasitas diri perempuan melalui pemberdayaan.

Kedua. Dominan di ranah domestik. Perempuan merupakan ujung tombak dan garda terdepan dari sebuah pengelolaan lingkungan hidup dalam rumah tangga, karena paling sering dan paling dekat dalam bersentuhan dengan unsur lingkungan hidup. Perempuan paling banyak berkiprah diwilayah domestik walaupun perempuan sudah berkiprah di ranah publik tetap banyak mengambil peran di ranah domestik. Kebersihan rumah tangga dan pengelolaan sampah rumah tangga dilakukan perempuan. Menjaga kebersihan rumah lebih banyak dilakukan kaum perempuan mulai dari membersihkan tempat tidur hingga pada kebersihan halaman rumah. Perempuan lebih banyak mengurusi sampah-sampah dalam rumah dan mengurusi limbah-limbah dari rumah tangga. 
Ketiga. Perempuan sebagai pengasuh dan pendidik dalam rumah tangga. Sebagai seorang ibu, kebanyakan pengasuhan dan pendidikan dalam rumah tangga diserahkan kepada seorang perempuan. Kebiasaan yang ditanamkan seorang ibu kepada anak-anak dalam rumah tangga merupakan pendidikan lingkungan hidup awal yang akan tertanam pada diri anak. Berdampak pada lingkungan hidup secara luas karena keluarga merupakan titik awal penanaman kebiasaan baik ataupun buruk pada generasi penerus bangsa. Apabila dalam keluarga tidak ditanmakan kebiasaan peduli lingkungan maka akan terbawa-bawa pada kebiasaan hingga kelak dewasa. Demikian juga sebaliknya jika jika dalam keluarga sudah dilakukan pembiasaan peduli lingkungan maka akan menjadi kebiasaan baik bagi anak-anak untuk konteks yang lebih luas dan menyeluruh.

\section{PENUTUP}

Pemberdayaan perempuan bermakna mulia karena mengurus sumberdaya manusia dalam keluarga, terutama anak-anak sebagai generasi penerus. Memberikan pendidikan yang terbaik untuk kaum perempuan, berarti secara tidak langsung memberikan pendidikan pada individu lainnya dalam sebuah keluarga, maka suksesnya suatu rumah tangga, sangat tergantung pada kemampuan dan potensi memadai dari perempuan, sebagai isteri dan ibu rumah tangga. Sehingga untuk mendukung keberadaan dan ketersediaan sumberdaya manusia (generasi penerus) berkualitas dan berdaya saing tinggi di masa depan maka perempuan penting diberdayakan khususnya dari sisi pendidikan termasuk dalam hal pendidikan lingkungan hidup.

Oleh karena itu strategi pengarusutamaan perempuan penting diposisikan di tempat utama dalam setiap strategi pembangunan. Pemberdayaan perempuan dalam meningkatkan kapasitas perempuan khususnya terkait dalam peningkatan pengetahuan lingkungan merupakan suatu yang perlu mendapat perhatian dari berbagai pihak. Agar sumber daya manusia yang cukup banyak jumlahnya di Indonesia dapat berdaya guna tinggi bagi pembangunan yang ramah lingkungan.

Peningkatan kapasitas diri perempuan, peningkatan pengetahuan melalui pemberdayaan belumlah cukup, jika tidak dibarengi dengan memberikan akses pada kaum perempuan untuk ikut berpartisipasi, mengontrol dan mengambil 
keputusan dari sebuah pembangunan termasuk pembangunan lingkungan hidup. Harapan diperoleh lingkungan hidup sehat, lestari dan layak huni dapat dirasakan manfaatnya oleh perempuan dan seluruh umat manusia. 


\section{DAFTAR RUJUKAN}

Adi, Isbandi Rukminto. 2012. Intervensi Komunitas \& Pengembangan Masyarakat Sebagai Upaya Pemberdayaan Masyarakat. Jakarta: Rajawali Pers.

Ali, Madekhan. 2007. Pemberdayaan Masyarakat. Jakarta:Averros Press.

Departemen Pendidikan Nasional. 2005. Kamus Besar Bahasa Indonesia. Edisi ketiga. Jakarta: Balai Pustaka.

Hogen, Christine. 2000. Facilitating Empowerment: a Handbook for Facilitatos, Trainers and individuals. London: Kogan Page Limited

Keraf, A.Sony. 2010. Etika Lingkungan Hidup. Jakarta: Penerbit Buku Kompas.

Ma'arif, Syafi'i, 2003. Pembangunan dalam Perspektif Gender. Malang: UMM Press.

Mardikanto, T.\& Soebiato, P. 2013. Pemberdayaan Masyarakat Dalam Perspektif Kebijakan Publik.Bandung: Alfabeta.

Soerjani, Muhammad. 2009. Pendidikan Lingkungan (Environmental Education) Sebagai Dasar Sikap dan Perilaku Bagi Kelangsungan Kehidupan Menuju Pembangunan Berkelanjutan. Jakarta: Institut Pendidikan dan Pengembangan Lingkungan.

Sri Marwanti1, Ismi Dwi Astuti. 2012. Model Pemberdayaan Perempuan Miskin Melalui Pengembangan Kewirausahaan Keluarga Menuju Ekonomi Kreatif Di Kabupaten Karanganyar.Jurnal Sepa : Vol. 9 No.1, $134-144$.

Sulistiyani. 2004. Kemitraan dan Model-Model Pemberdayaan Masyrakat. Yokyakarta: Gava Media.

Sumpeno, Wahyudin. 2009. Sekolah Masyarakat Penerapan Rapid Training Design Dalam Pelatihan Berbasis Masyarakat. Yogyakarta: Pustaka Pelajar

Zoer'aini Djamal Irwan. 2009. Besarnya Eksploitasi Perempuan Dan Lingkungan Di Indonesia. Jakarta: Alex Media Komputindo. 